\title{
Winter Particulate Pollution over Raipur, India
}

\author{
Nitin Kumar Jaiswal ${ }^{1}$; Shobhana Ramteke ${ }^{2}$; Khageshwar Singh Patel ${ }^{3}$; Harald Saathoff ${ }^{4}$; \\ Silvia Nava; ${ }^{5}$ Franco Lucarelli ${ }^{6}$; Eduardo Yubero ${ }^{7}$; and Mar Viana ${ }^{8}$
}

\begin{abstract}
Particulate air pollution during the winter season in the urban regions of India is severe due to substantial fuel and mineral combustion in adverse climatic conditions. In this work, chemical characteristics and sources of coarse particulate matter (PM $\mathrm{P}_{10}$ ) and particulates associated chemicals during winter period of years 2006-2013 in the polluted city of Raipur, Chhattisgarh, India, are reported. The ambient air coarse particulate $\left(\mathrm{PM}_{10}\right)$ concentration during the winter period of 2006-2007 ranged from 221 to $760 \mu \mathrm{g} \mathrm{m}{ }^{-3}$. The major fraction of the $\mathrm{PM}_{10}$ was composed of organic carbon, elemental carbon, iron, calcium, and sulfate. Their concentrations were remarkably reduced in the rainy season due to high wind speeds (around $10 \mathrm{kmh}^{-1}$ ) and removal with rain. The concentration variations and sources of PM and associated chemical species (i.e., carbons, ions, and metals) in the ambient air are discussed. DOI: 10.1061/(ASCE)HZ.21535515.0000444. (C) 2019 American Society of Civil Engineers.
\end{abstract}

Author keywords: Particulate matters; Carbons; Metals; Ions; Sources.

\section{Introduction}

Particulate matter (PM) is composed of a wide variety of airborne materials (i.e., dust, smoke, and soot, among others), which are directly emitted into the air or result from the transformation of gaseous pollutants due to natural and anthropogenic sources (WHO 2006). PM has been reported as criteria pollutants by the USEPA (USEPA 2010). PM ( $\leq 10 \mu \mathrm{m})$ is of most concern for its effects on human health, i.e., chronic lung disease and asthma, lung cancer, heart attacks, exacerbation of chronic obstructive pulmonary disease (COPD), premature death, preterm birth, and low birth weight, among other (Ferrante et al. 2015). Some metals interact with enzymes, cell components, or DNA, for example, to cause adverse

\footnotetext{
${ }^{1}$ Assistant Professor, Dept. of Chemistry, Institute for Technology and Management Univ., Uparwara, Raipur 493661, India. Email: jaiswalnitink@ gmail.com

${ }^{2}$ Ph.D. Student, School of Studies in Environmental Science, Pt. Ravishankar Shukla Univ., Raipur 492010, India. Email: shubrmtk21 @ gmail.com

${ }^{3}$ Professor Emeritus, School of Studies in Chemistry, Pt. Ravishankar Shukla Univ., Raipur 492010, India (corresponding author). Email: patelkhageshwarsingh@gmail.com

${ }^{4}$ Scientist, Institute for Meteorology and Climate Research, Karlsruhe Institute of Technology, Karlsruhe 76131, Germany. Email: harald .saathoff@imk.fzk.de

${ }^{5}$ Scientist, Dept. of Physics, Univ. of Florence and Istituto Nazionale di Fisica Nucleare, I-50019 Florence, Italy. Email: nava@fi.infn.it

${ }^{6}$ Associate Professor, Dept. of Physics, Univ. of Florence and Istituto Nazionale di Fisica Nucleare, I-50019 Florence, Italy. Email: lucarelli@ fi.infn.it

${ }^{7}$ Professor, Atmospheric Pollution Laboratory, Dept. of Applied Physics, Miguel Hernandez Univ., Avda de la Universidad S/N, 03202 Elche, Spain. Email: eyubero@umh.es

${ }^{8}$ Scientist, Institute for Environmental Assessment and Water Research, Institute of Environmental Assessment and Water research Spanish National Research Council, C/Jordi Girona 18, 08034 Barcelona, Spain. Email: mar.viana@gmail.com

Note. This manuscript was submitted on December 11, 2018; approved on March 12, 2019; published online on June 19, 2019. Discussion period open until November 19, 2019; separate discussions must be submitted for individual papers. This paper is part of the Journal of Hazardous, Toxic, and Radioactive Waste, (C) ASCE, ISSN 2153-5493.
}

health effects (Fortoul et al. 2015). The optically active components (e.g., elemental and organic carbon and sulfate) of the particulates affect precipitation and cloud-cover events (Bell and Holloway 2007). High particulate concentrations in ambient air have caused synoptic weather in several parts of the world (Awad and Mashat 2016; Ding et al. 2016; Han et al. 2015; Sati and Mohan 2014; Guttikunda et al. 2013). The distribution, composition, and origins of particulates in ambient air of several regions have been reported (Zeb et al. 2018; Ding et al. 2016; Pan et al. 2015; Xu et al. 2015; Tao et al. 2014; Satsangi et al. 2013; Singh et al. 2013; Yadav and Satsangi 2013; Khillare and Sarkar 2012; Kulshrestha et al. 2009; Lakhani et al. 2008; Gupta et al. 2007; Yttri et al. 2007; Begum et al. 2006; Mouli et al. 2006; Oanh et al. 2006; Gupta and Kumar 2006; Duan et al. 2005; Sillanpaa et al. 2005). The aerosol dynamics (i.e., distribution, composition, sources, and impacts) in developing countries like India are complicated due to scarce aerosol data, high emissions, and severe health hazards. In this work, concentration variations, composition, and sources of the chemical species associated with ambient particulates in the most polluted city, Raipur, during the winter season of years 2006-2013 are described.

\section{Materials and Methods}

\section{Study Area}

The capital city of the Indian state of Chhattisgarh, Raipur $\left(21^{\circ} 24^{\prime} \mathrm{N} ; 81^{\circ} 63^{\prime} \mathrm{E}\right)$ is surrounded by coal- and mineral-based industries and was therefore selected for the proposed investigation. The Urla industrial area is spread over around 300 ha in the northeast direction, with installation of wide range of various industries. Another industrial area, Silrara, is spread over around 900 ha in the east direction and is home to industries such as sponge iron units and ferroalloy plants, among others. Similarly, many cement plants are located in the east direction of the city within an approximate $70-\mathrm{km}$ radius. The largest steel plant (Bhilai) is located around $20 \mathrm{~km}$ away in the northwest direction from Raipur. The Borai, Durg industrial area (around 192 ha) is located approximately $40 \mathrm{~km}$ away from Raipur in the north-south direction. At least 300 rice mills are running in neighboring cities such as Durg, 
Rajnandgaon, Tilda, Bhatapara, Arang, Rajim Nawapara, and Dhamtari, among others. A large industrial city, Korba, where several coal mines and thermal power plants operate, lies in the northeast direction around $150 \mathrm{~km}$ away from the city.

\section{Sampling of Particulate}

The $\mathrm{PM}_{10}$ sample was collected by using portable air sampler University of California (UC Davis) over a 47-mm (Whatmann QMA, Darmstadt, Germany) quartz filter at flow rate of 19.4 $\mathrm{L} \mathrm{min}^{-1}$. Similarly, the suspended particulate matter (SPM) sample was collected by use of a high-volume air sampler (flow rate of $1,062.5 \mathrm{~L} \mathrm{~min}^{-1}$ ) on the quartz filter (Whatmann QMA, $\left.515.6 \mathrm{~cm}^{-2}\right)$. They were heated beforehand $\left(600^{\circ} \mathrm{C}\right.$ for $\left.6 \mathrm{~h}\right)$ to reduce blank values. The samplers were installed on the second floor of building (above a height of around $10 \mathrm{~m}$ from the ground) to minimize dust originating from ground-level activities. The filter was loaded in the sampler and run to collect particulates over $12 \mathrm{~h}$ (6:00 a.m.-6:00 p.m.). In similar ways, one collection blank was prepared. After collection, the dismounted filter was kept in petri dish and transferred to the laboratory. Similarly, a total of $18 \mathrm{PM}_{10}$ and SPM samples were collected from 15 sites of the city in the winter period of (2006-2007, Fig. 1). For temporal studies, $15 \mathrm{PM}_{10}$ samples from three locations i.e., Kota, Kalibadi, and Sankara, were collected in the month of January during years 2008-2013. All loaded filters were kept in a petri dish and refrigerated at $-4^{\circ} \mathrm{C}$ until the analysis.

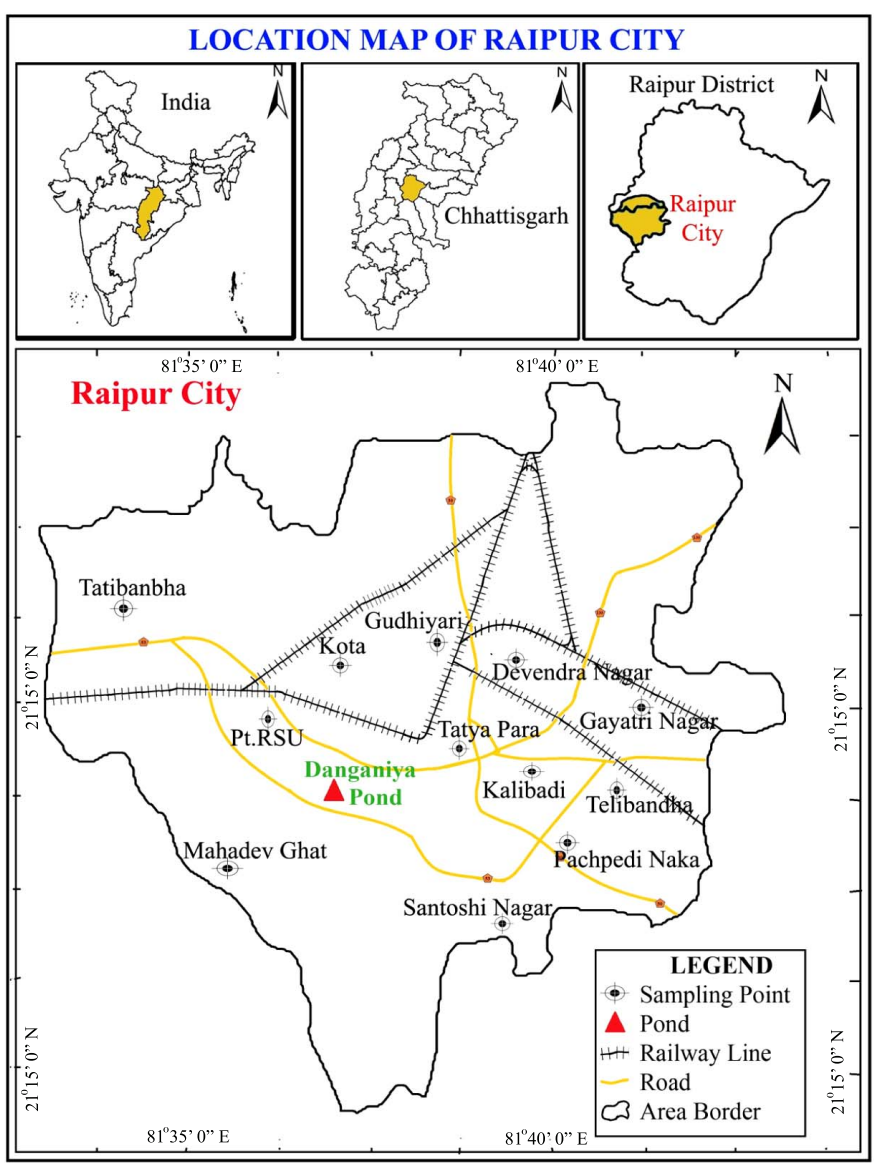

Fig. 1. Map of India with location of the sampling sites in Raipur City and major possible particle sources.

\section{Analysis of Particulate Carbons}

The thermal method was used for analysis of the organic (OC) and elemental carbon (EC) as prescribed in the literature (VDI German 1996). All carbons were converted into $\mathrm{CO}_{2}$ by subsequent measurement with a nondispersive infrared (IR) detector. The sum total concentration of OC and EC was considered as total carbon (TC) in this work. The OC and EC analyses were carried out in triplicate. Their relative standard deviation (RSD) values were observed within $\leq \pm 3.0 \%$.

\section{Analysis of Elements}

The proton-induced X-ray emission (PIXE) technique was used for measurement of the metal content of the filter. The Istituto Nazionale di Fisica Nucleare Tandetron (INFN, Florence, Italy) accelerator 3-MV facility in Florence, Italy, was used as external beam for the excitation of the elements (Calzolai et al. 2006). The RSD values for the triplicate analysis of the elements fell within $\leq \pm 5 \%$.

\section{Analysis of Water-Soluble lons}

The ion content of PM was leached out with deionized water $(15 \mathrm{~mL}$, $0.054 \mu \mathrm{S} \mathrm{cm}^{-1}$ ) by sonicating at $60^{\circ} \mathrm{C}$ for 1 day (around $24 \mathrm{~h}$ ). An ion chromatograph (Dionex DX120, Sunnyvale, California) equipped with anion and cation separation columns and a conductivity detector was used for analysis of the ions. An aliquot of the filtered sample ( $200 \mu \mathrm{L})$ was injected into the chromatography for quantifying the ions. The bicarbonate $(9 \mathrm{mM})$ and methane sulfonic $(20 \mathrm{mM})$ eluents were employed as leaching agents for the anions and cations, respectively. The RSD values for triplicate analysis of ions were observed between $\pm 5 \%$ and $10 \%$.

\section{Quality Assurance and Quality Control}

The precision of the portable air sampler was determined by using a 2,300-sequential speciation air sampler [Partisol model (Thermo Fisher Scientific Air Quality Instruments, Franklin, Massachusetts)]. Similarly, a total of six samples $(2 \times 3)$ by both samplers were collected. The masses of the PM were determined by a Mettler M3 electronic (Columbus, Ohio) balance after blank correction. The RSD values $(n=3)$ for $\mathrm{PM}_{10}$ collections with the portable and Partisol samplers fell in between $\pm 2.9 \%$ and $2.2 \%$, respectively. The carbon analyzer was calibrated with known quantities of propane gases and $\mathrm{CO}_{2}$ for analysis of the samples. The sensitivity of the PIXE technique for studied elements was standardized by using the reference aerosol filter sample. For ion chromatographic analysis, the calibration curves were prepared by injecting different concentrations of the standard solutions (Emanuel Merck, Darmstadt, Germany) for determination of ions. The precision of the analysis in the proposed work was expressed in terms of standard deviation $( \pm$ SDT).

\section{Results and Discussion}

\section{Meteorology}

The meteorology remarkably influences the PM concentration in ambient air. The values of temperature $(T)$, relative humidity $(\mathrm{RH})$, wind speed (WS), and sunshine (SS) during the period December 2006-February 2007 were recorded in the range of $16.7^{\circ} \mathrm{C}-23.4^{\circ} \mathrm{C}, 52 \%-70 \%, 1.5-5.9 \mathrm{~km} \mathrm{~h}^{-1}$, and $5.3-9.4 \mathrm{~h} \mathrm{day}^{-1}$ with an average value of $20^{\circ} \mathrm{C}, 59 \%, 2.7 \mathrm{~km} \mathrm{~h}^{-1}$, and $8.2 \mathrm{hday}^{-1}$, respectively. The lowest wind speed (around $1.0 \mathrm{~km} \mathrm{~h}^{-1}$ ) was 
Table 1. Particulate concentration in winter 2006-2007 at various locations in Raipur, India

\begin{tabular}{|c|c|c|c|c|c|}
\hline S. No. & Sampling date & Sampling site & Type & Mode & $\begin{array}{l}\text { Concentration in } \\
\text { air }\left(\mu \mathrm{g} \mathrm{m}^{-3}\right) \\
\end{array}$ \\
\hline 1 & December 12, 2006 & Devendra Nagar (DN) & $\mathrm{CA}$ & $\mathrm{PM}_{10}$ & 696 \\
\hline 2 & January 3, 2007 & Gudiari (G) & $\mathrm{CA}$ & $\mathrm{PM}_{10}$ & 650 \\
\hline 3 & January 4, 2007 & Telebandha (TL) & $\mathrm{CA}$ & $\mathrm{PM}_{10}$ & 321 \\
\hline 4 & January 6, 2007 & Gayatri Nagar (GN) & RA & $\mathrm{PM}_{10}$ & 265 \\
\hline 5 & January 8, 2007 & Santoshi Nagar (SN) & RA & $\mathrm{PM}_{10}$ & 577 \\
\hline 6 & January 9, 2007 & Kalibadi (KB) & $\mathrm{CA}$ & $\mathrm{PM}_{10}$ & 462 \\
\hline 7 & January 10, 2007 & Pachperi Naka (PN) & $\mathrm{CA}$ & $\mathrm{PM}_{10}$ & 308 \\
\hline 8 & January 12, 2007 & Dangania (D) & RA & $\mathrm{PM}_{10}$ & 221 \\
\hline 9 & January 14, 2007 & Mahadevghat Road (MR) & RA & $\mathrm{PM}_{10}$ & 510 \\
\hline 10 & January 15, 2007 & RS University (RSU) & $\mathrm{RA}$ & $\mathrm{PM}_{10}$ & 295 \\
\hline 11 & January 16, 2007 & Tatibandh (TB) & RA & $\mathrm{PM}_{10}$ & 304 \\
\hline 12 & January 19, 2007 & Kota $(\mathrm{K})$ & RA & $\mathrm{PM}_{10}$ & 353 \\
\hline 13 & January 21, 2007 & Tatyapara (TP) & $\mathrm{CA}$ & $\mathrm{PM}_{10}$ & 420 \\
\hline 14 & February 7, 2007 & Tara Industrial area (TI) & IA & $\mathrm{PM}_{10}$ & 384 \\
\hline 15 & February 8, 2007 & Sankara (SK) & IA & $\mathrm{PM}_{10}$ & 760 \\
\hline 16 & February 5, 2007 & Sankera (SK) & IA & SPM & 1,266 \\
\hline 17 & February 5, 2007 & Siltera (SL) & IA & SPM & 1,150 \\
\hline 18 & February 7, 2007 & Tara Industrial area (TI) & IA & SPM & 1,577 \\
\hline
\end{tabular}

Note: $\mathrm{CA}=$ commercial area; $\mathrm{IA}=$ industrial area; and $\mathrm{RA}=$ residential area.

observed during months of December and January. Thereafter, the wind speed steadily increased at rate of around $1.5 \mathrm{~km} \mathrm{~h}^{-1}$, reaching maxima (round $10 \mathrm{~km}$ ) in the months of June and July. After July, the wind speed again steadily decreased to its minima in the month of December. Due to the adverse climatic conditions during the months of December and January, air pollutants could not export to the outside environment and therefore increased several times higher than the mean values, causing several climatic and health hazards.

\section{Distribution of Particulate Matter}

High PM content in the ambient air is responsible for the origin of complex environmental and health issues in urban areas. The PM concentration in the air during period from December 2006 to February 2007 is summarized in Table 1. Wide $\mathrm{PM}_{10}$ $(n=15)$ and SPM $(n=3)$ concentration variations in the air were observed: $221-760$ and 1,150-1,577 $\mu \mathrm{g} \mathrm{m}^{-3}$ with an average value of $435 \pm 168$ and $1,331 \pm 221 \mu \mathrm{g} \mathrm{m}^{-3}$, respectively. The maximum $\mathrm{PM}_{10}$ mass concentration in the air was seen in the industrial (i.e., Sankara) and commercial areas (i.e., Devendra Nagar and Gudhiyari). In contrast, a significant high mass concentration of $\mathrm{PM}_{10}$ in sites such as Santoshi Nagar and Mahadev ghat were also observed, but these were expected due to transport of effluents from the Bhilai Steel Plant. The $\mathrm{PM}_{10} / \mathrm{SPM}$ average ratio was observed to be 0.33 . The wind speed of the air mass varied around $1.0-10 \mathrm{~km} \mathrm{~h}^{-1}$ with the minimum and maximum value in December and July, respectively. The concentration of $\mathrm{PM}_{10}$ had a good negative correlation $(r=-0.86)$ with the wind speed of the air mass. The minimum $\mathrm{PM}_{10}$ concentration in the air during July was marked due to the high wind speed $\left(\geq 10 \mathrm{~km} \mathrm{~h}^{-1}\right)$ and the $\mathrm{PM}_{10}$ removal with rain. The average air-quality standard for urban areas proposed by the USEPA was used as the air-quality criteria. The $\mathrm{PM}_{10}$ concentration in Raipur City during the winter period was found to be around eightfold greater than the permissible limit of $50 \mu \mathrm{g} \mathrm{m}^{-3}$ (USEPA 2004). Severe ambient particulate pollution in Raipur City was identified, which was much higher than values observed in other parts of the country (Gupta et al. 2007; Begum et al. 2006; Gupta and Kumar 2006; Oanh et al. 2006).

\section{Distribution of Carbon}

The major fractions of the aerosols are composed of elemental carbon [EC or black carbon (BC)] and organic carbon. Among them, EC is an optically active component of the PM, being the second culprit for climate change after $\mathrm{CO}_{2}$. In addition, they also adsorbed heavy metals and organic compounds. The OC were composed of a variety of organic compounds of climatic and environmental interests. The concentration of $\mathrm{OC}_{10}, \mathrm{EC}_{10}, \mathrm{TC}_{10}$, $\mathrm{OC}_{\mathrm{SPM}}, \mathrm{EC}_{\mathrm{SPM}}$, and $\mathrm{TC}_{\mathrm{SPM}}$ in the air in the range of 14-109, 11-114, 25-219, 20-35, 41-101, and 64-136 $\mu \mathrm{g} \mathrm{m}^{-3}$, respectively (Table 2). The $\mathrm{OC}_{10} / \mathrm{OC}_{\mathrm{SPM}}$ and $\mathrm{EC}_{10} / \mathrm{EC}_{\mathrm{SPM}}$ average ratios were found to be 1.37 and 0.60 , respectively. Tremendously high concentrations of EC were observed in the industrial (i.e., Sankara) and commercial areas (i.e., Devendra Nagar and Gudhiyari), as expected due to emissions from industrial sources. The EC concentration with the $\mathrm{PM}_{10}$ had fair correlation $(r=0.68)$. However, the maximum OC concentration was observed in the commercial areas, i.e., Devendra Nagar and Gudhiyari, which may be due to vehicle emissions. The OC concentration with the $\mathrm{PM}_{10}$ had fair correlation $\left(r^{2}=0.84\right)$ with the $\mathrm{PM}_{10}$. However, the concentration of $\mathrm{OC}$ and EC with the wind speed of air mass had a fair negative correlation ( $r=-0.81$ to -0.85 to 0.83 ) with their lowest concentrations in the month of July, similar to the $\mathrm{PM}_{10}$ scenario. The average ratios of $\mathrm{OC}_{10} / \mathrm{PM}_{10}$ and $\mathrm{EC}_{10} / \mathrm{PM}_{10}$ were observed to be 0.08 and 0.09 , respectively. The $\mathrm{OC}_{10} / \mathrm{EC}_{10}$ ratio was between 0.28 and 1.74 , with an average value of $0.99 \pm 0.36$. The concentrations of the EC and OC seem to be much higher than the values observed in other locations of the country and world (Gupta et al. 2017; Costa et al. 2016; Ding et al. 2016; Xu et al. 2015; Yttri et al. 2007; Duan et al. 2005; Sillanpaa et al. 2005; Latha and Badrinath 2003).

\section{Distribution of Major Elements}

The major fraction of the aerosols was composed of crustal elements. The ambient air concentrations of $\mathrm{Al}, \mathrm{P}, \mathrm{Ti}, \mathrm{Cr}, \mathrm{Mn}, \mathrm{Fe}, \mathrm{Cu}$, $\mathrm{Zn}$, and $\mathrm{Zr}$ (associated with $\mathrm{PM}_{10}$ ) varied as 6.5-20.3, 0.2-0.4, $1.0-2.9,0.1-0.2,0.5-2.4,14-78,0-0.2,0-1.3$, and $0-0.3 \mu \mathrm{g} \mathrm{m}^{-3}$, respectively (Table 3 ). 
Table 2. Mass concentration of organic carbon (OC), black carbon (BC), and total carbon (TC)

\begin{tabular}{|c|c|c|c|c|c|c|}
\hline \multirow[b]{2}{*}{ S. No. } & \multicolumn{3}{|c|}{$\begin{array}{l}\text { Concentration } \\
\text { in air }\left(\mu \mathrm{g} \mathrm{m}^{-3}\right)\end{array}$} & \multicolumn{3}{|c|}{$\begin{array}{c}\text { Concentration } \\
\text { in PM }(\%)\end{array}$} \\
\hline & $\mathrm{OC}$ & $\mathrm{EC}$ & $\mathrm{TC}$ & $\mathrm{OC}$ & $\mathrm{EC}$ & $\mathrm{TC}$ \\
\hline 1 & 109 & 110 & 219 & 15.7 & 15.8 & 31.5 \\
\hline 2 & 107 & 96 & 203 & 16.5 & 14.8 & 31.3 \\
\hline 3 & 28 & 25 & 53 & 8.7 & 7.8 & 16.5 \\
\hline 4 & 27 & 32 & 59 & 10.2 & 12.1 & 22.3 \\
\hline 5 & 33 & 19 & 52 & 5.7 & 3.3 & 9.0 \\
\hline 6 & 38 & 30 & 68 & 8.2 & 6.5 & 14.7 \\
\hline 7 & 26 & 19 & 45 & 8.4 & 6.2 & 14.6 \\
\hline 8 & 14 & 11 & 25 & 6.3 & 5.0 & 11.3 \\
\hline 9 & 26 & 28 & 54 & 5.1 & 5.5 & 10.6 \\
\hline 10 & 20 & 22 & 42 & 6.8 & 7.5 & 14.3 \\
\hline 11 & 15 & 23 & 38 & 4.9 & 7.6 & 12.5 \\
\hline 12 & 15 & 16 & 31 & 4.2 & 4.5 & 8.7 \\
\hline 13 & 25 & 26 & 51 & 6.0 & 6.2 & 12.2 \\
\hline 14 & 18 & 39 & 57 & 4.7 & 10.2 & 14.9 \\
\hline 15 & 32 & 114 & 146 & 4.2 & 15.0 & 19.2 \\
\hline Mean $\mathrm{PM}_{10}$ & 36 & 41 & 76 & 7.7 & 8.5 & 16.2 \\
\hline$\pm \mathrm{SD}$ & 30 & 35 & 61 & 3.8 & 4.1 & 7.1 \\
\hline 16 & 23 & 41 & 64 & 1.8 & 3.2 & 5 \\
\hline 17 & 20 & 63 & 83 & 1.7 & 5.5 & 7.2 \\
\hline 18 & 35 & 101 & 136 & 2.2 & 6.4 & 8.6 \\
\hline Mean SPM & 26 & 68 & 94 & 1.9 & 5.0 & 6.9 \\
\hline$\pm \mathrm{SD}$ & 8 & 30 & 37 & 0.3 & 1.7 & 1.8 \\
\hline
\end{tabular}

Note: $\mathrm{SD}=$ standard deviation.

Table 3. Mass concentration of trace elements in ambient air $\left(\mu \mathrm{g} \mathrm{m}^{-3}\right)$

\begin{tabular}{lrcccccccc}
\hline S. No. & \multicolumn{1}{c}{$\mathrm{Al}$} & $\mathrm{P}$ & $\mathrm{Ti}$ & $\mathrm{Cr}$ & $\mathrm{Mn}$ & $\mathrm{Fe}$ & $\mathrm{Cu}$ & $\mathrm{Zn}$ & $\mathrm{Zr}$ \\
\hline 1 & 13.0 & 0.2 & 2.0 & 0.1 & 2.4 & 28 & 0.20 & 1.2 & 0.2 \\
2 & 10.2 & 0.4 & 1.6 & 0.1 & 1.3 & 26 & 0.10 & 0.3 & 0.1 \\
3 & 7.3 & 0.2 & 1.2 & 0.1 & 1.0 & 16 & 0.01 & 0.3 & 0.2 \\
4 & 6.5 & 0.3 & 1.0 & 0.1 & 0.5 & 16 & 0.01 & 0.2 & 0.0 \\
5 & 15.6 & 0.3 & 2.5 & 0.1 & 1.2 & 39 & 0.01 & 0.3 & 0.3 \\
6 & 11.3 & 0.4 & 1.6 & 0.1 & 1.0 & 25 & 0.05 & 0.2 & 0.2 \\
7 & 6.8 & 0.2 & 1.2 & 0.1 & 0.5 & 14 & 0.01 & 0.2 & 0.3 \\
8 & 6.5 & 0.3 & 1.0 & 0.1 & 0.8 & 15 & 0.02 & 0.2 & 0.2 \\
9 & 12.9 & 0.3 & 1.9 & 0.2 & 2.2 & 38 & 0.07 & 0.6 & 0.2 \\
10 & 8.4 & 0.2 & 1.2 & 0.1 & 1.1 & 20 & 0.04 & 0.2 & 0.3 \\
11 & 9.7 & 0.4 & 1.5 & 0.1 & 1.1 & 19 & 0.01 & 0.3 & 0.3 \\
12 & 10.2 & 0.3 & 1.6 & 0.2 & 0.8 & 24 & 0.04 & 0.3 & 0.3 \\
13 & 13.7 & 0.3 & 1.9 & 0.1 & 0.9 & 26 & 0.04 & 0.0 & 0.3 \\
14 & 10.6 & 0.4 & 2.0 & 0.1 & 0.6 & 28 & 0.04 & 0.2 & 0.3 \\
15 & 20.3 & 0.3 & 2.9 & 0.2 & 2.2 & 78 & 0.04 & 1.3 & 0.2 \\
Mean PM & 10.9 & 0.3 & 1.7 & 0.1 & 1.2 & 27.5 & 0.05 & 0.4 & 0.2 \\
\pm SD & 3.8 & 0.1 & 0.5 & 0.0 & 0.6 & 15.9 & 0.05 & 0.4 & 0.1 \\
16 & 20.7 & 0.1 & 2.8 & 0.2 & 2.7 & 82 & 1.80 & 0.2 & 0.2 \\
17 & 15.5 & 0.2 & 2.4 & 0.2 & 0.6 & 54 & 0.10 & 0.6 & 0.1 \\
18 & 23.6 & 0.3 & 3.9 & 0.3 & 2.7 & 87 & 1.10 & 0.1 & 0.2 \\
Mean SPM & 19.9 & 0.2 & 3.0 & 0.2 & 2.0 & 74.3 & 1.0 & 0.3 & 0.2 \\
\pm SD & 4.1 & 0.1 & 0.8 & 0.1 & 1.2 & 17.8 & 0.9 & 0.3 & 0.1 \\
\hline & & & & & & & & &
\end{tabular}

The concentration of examined elements in the SPM varied as 15.5-23.6, 0.1-0.3, 2.4-3.9, 0.2-0.3, 0.6-2.7, 54-87, 0.1-1.8, $0.1-0.6$, and $0.1-0.2 \mu \mathrm{g} \mathrm{m}^{-3}$, respectively (Table 3). Among them, the concentration of elements $\mathrm{Al}, \mathrm{Ti}, \mathrm{Mn}, \mathrm{Fe}, \mathrm{Cu}$, and $\mathrm{Zn}$ with $\mathrm{PM}_{10}$ had a fair correlation $(r=0.63-0.83)$, unlike $\mathrm{P}, \mathrm{Cr}$, and $\mathrm{Zr}$. However, their concentrations with wind speed had a negative partial correlation $(r=-0.45$ to -0.47$)$. The concentration ratio of the corresponding elements (associated with SPM and $\mathrm{PM}_{10}$ ) was found to be $1.9,0.7,1.8,2.0,1.7,2.7,20,0.8$, and 1.0 , respectively.
Table 4. Mass concentration of water aerosol soluble ions in ambient air $\left(\mu \mathrm{g} \mathrm{m}^{-3}\right)$

\begin{tabular}{lrrrrrrrr}
\hline S. No. & $\mathrm{Na}^{+}$ & \multicolumn{1}{c}{$\mathrm{K}^{+}$} & $\mathrm{Mg}^{2+}$ & $\mathrm{Ca}^{2+}$ & $\mathrm{NH}_{4}^{+}$ & $\mathrm{SO}_{4}^{2-}$ & $\mathrm{NO}_{3}^{-}$ & $\mathrm{Cl}^{-}$ \\
\hline 1 & 3.8 & 15.9 & 1.5 & 26.6 & 1.9 & 38.4 & 14.3 & 12.0 \\
2 & 4.2 & 9.3 & 1.5 & 29.4 & 0.8 & 17.7 & 13.5 & 13.9 \\
3 & 5.3 & 2.9 & 1.0 & 21.1 & 1.7 & 14.9 & 8.6 & 3.9 \\
4 & 3.0 & 2.4 & 0.7 & 16.4 & 0.8 & 8.5 & 7.6 & 3.1 \\
5 & 10.8 & 2.3 & 1.1 & 31.0 & 0.2 & 11.5 & 5.8 & 3.3 \\
6 & 6.2 & 4.7 & 1.2 & 25.7 & 2.9 & 23.2 & 10.5 & 4.2 \\
7 & 6.2 & 3.7 & 1.0 & 20.4 & 1.2 & 12.9 & 6.0 & 3.2 \\
8 & 3.8 & 1.7 & 0.6 & 11.8 & 1.2 & 11.0 & 3.5 & 1.0 \\
9 & 5.9 & 3.5 & 1.3 & 30.2 & 4.0 & 28.6 & 13.9 & 2.2 \\
10 & 5.9 & 4.0 & 1.3 & 17.6 & 4.6 & 25.7 & 11.5 & 5.1 \\
11 & 6.5 & 1.8 & 0.8 & 12.6 & 0.8 & 12.1 & 6.2 & 2.9 \\
12 & 8.1 & 2.6 & 1.3 & 22.9 & 0.7 & 15.5 & 6.7 & 2.7 \\
13 & 6.3 & 2.8 & 1.1 & 19.9 & 0.8 & 11.5 & 5.4 & 4.0 \\
14 & 8.0 & 2.4 & 1.2 & 11.9 & 0.9 & 12.7 & 4.6 & 3.4 \\
15 & 4.4 & 3.2 & 1.3 & 11.5 & 1.5 & 17.0 & 4.3 & 5.5 \\
Mean PM & 5.9 & 4.2 & 1.1 & 20.6 & 1.6 & 17.4 & 8.2 & 4.7 \\
\pm SD & 2.0 & 3.7 & 0.3 & 6.9 & 1.3 & 8.2 & 3.7 & 3.5 \\
16 & 1.5 & 1.5 & 0.6 & 9.0 & 1.3 & 12.7 & 3.3 & 0.8 \\
17 & 1.8 & 0.8 & 0.7 & 10.5 & 0.2 & 8.7 & 1.9 & 0.6 \\
18 & 2.2 & 2.9 & 1.3 & 14.0 & 0.8 & 18.7 & 6.1 & 1.4 \\
Mean SPM & 1.8 & 1.7 & 0.9 & 11.2 & 0.8 & 13.4 & 3.8 & 0.9 \\
\pm SD & 0.4 & 1.1 & 0.4 & 2.6 & 0.6 & 5.0 & 2.1 & 0.4 \\
\hline & & & & & & & &
\end{tabular}

Among them, the crustal elements $\mathrm{Al}, \mathrm{Ti}, \mathrm{Cr}, \mathrm{Mn}, \mathrm{Fe}$, and $\mathrm{Cu}$ were moderately to strongly enriched in the SPM modes. The maximum concentration of the elements was seen in the Tara and Sankara industrial areas, probably due to emissions from industrial sources. Significantly high metal concentrations in the ambient air of Raipur City were halted, which were observed to be much higher than values detected in other parts of the country and world, probably due to the operation of several coal- and mineral-based industries in the study area (Pan et al. 2015; Yadav and Satsangi 2013; Khillare and Sarkar 2012; Lakhani et al. 2008; Mouli et al. 2006).

\section{Distribution of Water-Soluble lons}

Ions in the ambient air were contributed by both local and distant sources. Remarkably high concentrations of ions $\left(\mathrm{Cl}^{-}, \mathrm{NO}_{3}^{-}, \mathrm{SO}_{4}^{2-}\right.$, $\mathrm{NH}_{4}^{+}, \mathrm{Na}^{+}, \mathrm{K}^{+}, \mathrm{Mg}^{2+}$, and $\mathrm{Ca}^{2+}$ ) associated with $\mathrm{PM}_{10}$ were identified. These ions were water-soluble and affected the quality of the rain and surface water. The concentrations of the aforementioned investigated ions varied in the range of 1.0-3.9, 3.5-14.3, 8.5-38.4, $0.2-4.6,3.0-10.8,1.7-15.9,0.6-1.5$, and $11.5-31.0 \mu \mathrm{g} \mathrm{m}^{-3}$, respectively (Table 4). Similarly, concentrations of examined ions associated with SPM were in the range of 0.6-1.4, 1.9-6.1, 8.7-18.7, 0.2-1.3, 1.5-2.2, 0.8-2.9, 0.6-1.3, and 9.0-14.0 $\mu \mathrm{g} \mathrm{m}^{-3}$, respectively. All ions except $\mathrm{Na}^{+}$and $\mathrm{NH}_{4}^{+}$had a poor correlation with the $\mathrm{PM}_{10}$ concentration $(r=0.36-0.73)$. Their concentration with wind speed had a partial negative correlation $(r \approx$ $-0.45)$, with the minimum values in July, unlike $\mathrm{Na}^{+}$and $\mathrm{NH}_{4}^{+}$ because they were contributed by other sources. $\mathrm{PM}_{10} / \mathrm{SPM}$ concentration ratios of $5.2,2.2,1.3,2.0,3.3,2.5,1.2$, and 1.8 for $\mathrm{Cl}^{-}$, $\mathrm{NO}_{3}^{-}, \mathrm{SO}_{4}^{2-}, \mathrm{NH}_{4}^{+}, \mathrm{Na}^{+}, \mathrm{K}^{+}, \mathrm{Mg}^{2+}$, and $\mathrm{Ca}^{2+}$ were observed. All ions were moderately to significantly enriched in the coarse modes. The $\sum \mathrm{PM}_{10} \mathrm{WSI}_{8}$ concentrations varied from 16.9 to $309 \mu \mathrm{g} \mathrm{m}^{-3}$ with an average value of $119 \pm 108 \mu \mathrm{g} \mathrm{m}^{-3}$. Significant higher loading of the ions in the air of commercial and residential locations (i.e., Devendra Nagar, Gudhiyari, Santoshi Nagar, and Mahadev Ghat) were observed. The concentration of $\mathrm{SO}_{4}^{2-}$ with the $\mathrm{NO}_{3}^{-}$in the $\mathrm{PM}_{10}$ had a fair correlation $(r=0.81)$, which may 


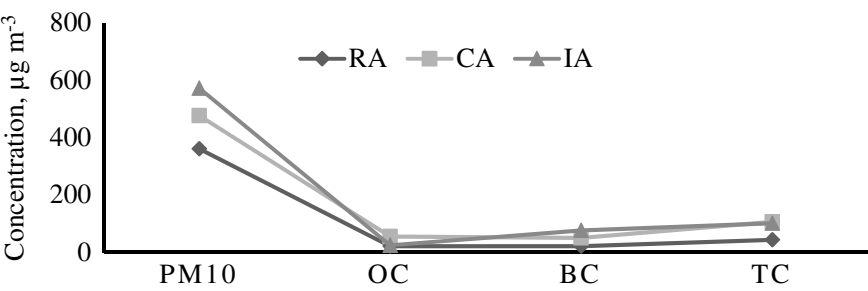

(a)

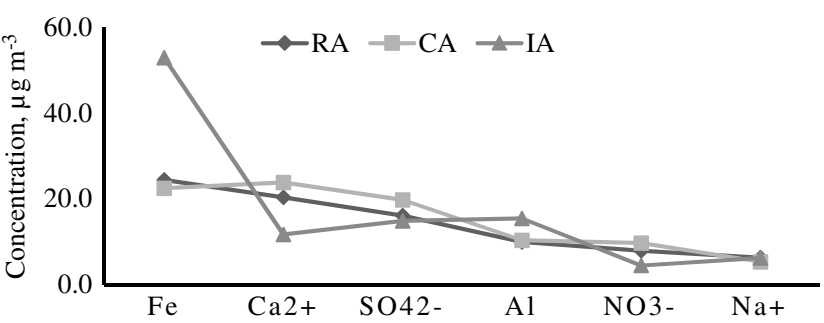

(b)

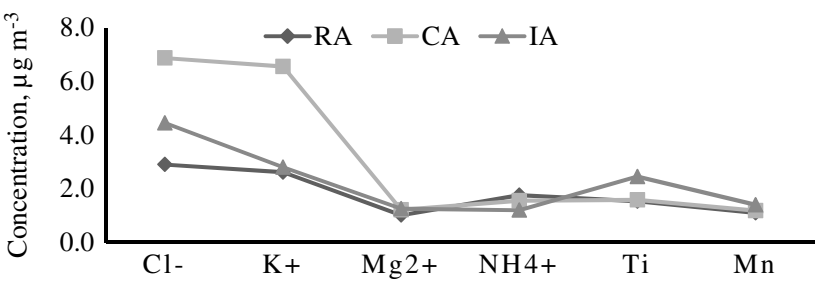

(c)

Fig. 2. Spatial variation of $P M$ and associated species. $R A=$ residential area; $\mathrm{CA}=$ commercial area; $\mathrm{IA}=$ industrial area; $\mathrm{OC}=$ organic carbon; $\mathrm{BC}=$ black/elemental carbon; and $\mathrm{TC}=$ total carbon .

be due to their formation by similar processes. The $\sum$ anion/ $\sum$ cation average equivalent ratio for the $\mathrm{PM}_{10}$ and SPM was 0.40 and 0.45 , respectively, indicating the alkaline nature of the air. The relative abundance of $7 \%, 13 \%, 27 \%, 3 \%, 9 \%, 7 \%, 2 \%$, and $32 \%$ for $\mathrm{Cl}^{-}, \mathrm{NO}_{3}^{-}, \mathrm{SO}_{4}^{2-}, \mathrm{NH}_{4}^{+}, \mathrm{Na}^{+}, \mathrm{K}^{+}, \mathrm{Mg}^{2+}$, and $\mathrm{Ca}^{2+}$ in the $\mathrm{PM}_{10}$ was identified. The major fraction $(59 \%)$ of the PM was contributed by ions $\mathrm{SO}_{4}^{2-}$ and $\mathrm{Ca}^{2+}$. Similar concentration ranges for these ions (associated with the coarse particulates) as those recorded for the ambient air of other parts of the country and China were observed (Tao et al. 2014; Satsangi et al. 2013; Singh et al. 2013; Kulshrestha et al. 2009).

\section{Spatial Distribution}

Concentrations of the chemical species related to PM in the air are affected by the meteorology and geography of the area. Higher concentrations of carbon and metals were observed in the industrial areas, probably due to coal and mineral combustion emissions (Fig. 2). In contrast, the highest concentrations of species OC, Ca, $\mathrm{K}, \mathrm{Cu}, \mathrm{Cl}^{-}, \mathrm{NO}_{3}^{-}$, and $\mathrm{SO}_{4}^{2-}$ were seen in the commercial areas, probably due to contributions from vehicular emissions and atmospheric inputs. However, the higher concentration of two species, $\mathrm{Na}$ and $\mathrm{NH}_{4}^{+}$, was marked in the residential area, which may be due to input from municipal wastes.

\section{Temporal Variations}

The concentrations of PM and associated species in the air are related to the frequency and strength of emission inventories. The vast industrialization and urbanization of Raipur City is occurring due to the easily available of natural resource materials,

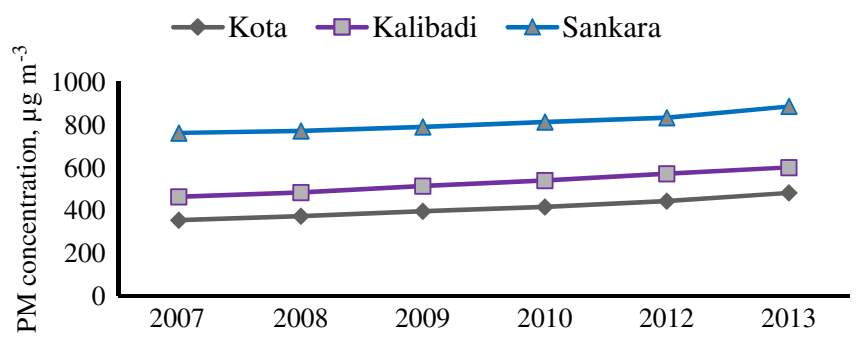

(a)



(b)

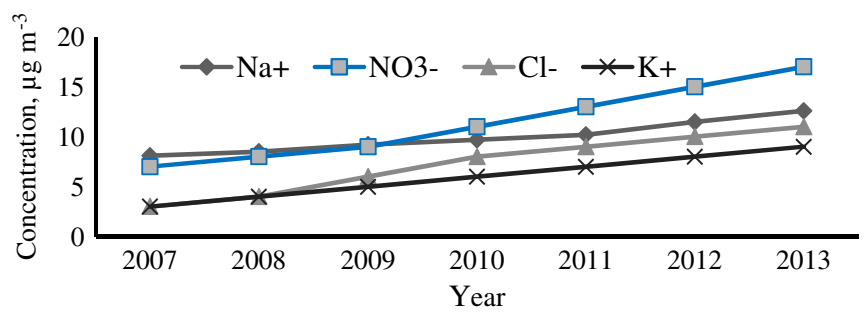

(c)

Fig. 3. Temporal variation of $\mathrm{PM}$ and associated elements. $\mathrm{OC}=$ organic carbon; and $\mathrm{BC}=$ black/elemental carbon.

i.e., coal, biomass, and minerals. The concentrations of PM and associated species were found to increase during 2006-2013, as expected due to increases in the quantum of population, industry, vehicles, and construction work, as shown in Fig. 3.

\section{Composition of Aerosols}

The urban aerosols are composed of carbons, metals, ions, and organics, among others. The fraction of $\mathrm{OC}, \mathrm{EC}(\mathrm{BC}), \mathrm{Fe}, \mathrm{Ca}^{2+}$, $\mathrm{SO}_{4}^{2-}, \mathrm{Al}, \mathrm{NO}_{3}^{-}, \mathrm{Na}^{+}, \mathrm{Cl}^{-}, \mathrm{K}^{+}, \mathrm{NH}_{4}^{+}, \mathrm{Ti}, \mathrm{Mg}, \mathrm{Mn}, \mathrm{P}, \mathrm{Zn}, \mathrm{Zr}, \mathrm{Cr}$, and $\mathrm{Cu}$ in the $\mathrm{PM}_{10}(n=15)$ was found to fall in the ranges of $4.2 \%-16.5 \%, 3.3 \%-15.8 \%, 4.0 \%-10.3 \%, 1.5 \%-6.2 \%, 2.0 \%-8.7 \%$, $1.6 \%-3.3 \%, 0.6 \%-3.9 \%, 0.6 \%-2.3 \%, 0.1 \%-2.1 \%, 0.4 \%-2.3 \%$, $0.03 \%-1.6 \%, 0.3 \%-0.5 \%, 0.2 \%-0.4 \%, 0.2 \%-0.4 \%, 0.03 \%-0.14 \%$, $0.01 \%-0.17 \%, 0.01 \%-0.10 \%, 0.01 \%-0.06 \%$, and $0.01 \%-0.03 \%$ with average values of $7.7 \%, 8.5 \%, 6.2 \%, 5.1 \%, 4.2 \%, 2.6 \%, 2.0 \%$, $1.5 \%, 1.0 \%, 0.9 \%, 0.4 \%, 0.4 \%, 0.3 \%, 0.3 \%, 0.08 \%, 0.08 \%, 0.06 \%$, $0.03 \%$, and $0.01 \%$, respectively. However, in the SPM, the fraction of all species except $\mathrm{Cu}$ was found in the lower orders. The total fraction of the carbons, metals, and water-soluble ions in the $\mathrm{PM}_{10}$ and SPM estimated was found to be $41.4 \%$ and $22.1 \%$, respectively. The uncertainty observed in the $\mathrm{PM}_{10}$ and SPM was $58.6 \%$ and $77.9 \%$, respectively.

\section{Sources}

Local industries, including Bhilai Steel Plant, fully encircle Raipur City. The highest concentrations of $\mathrm{PM}_{10}, \mathrm{EC}, \mathrm{K}^{+}, \mathrm{Fe}$, and $\mathrm{Al}$ were 


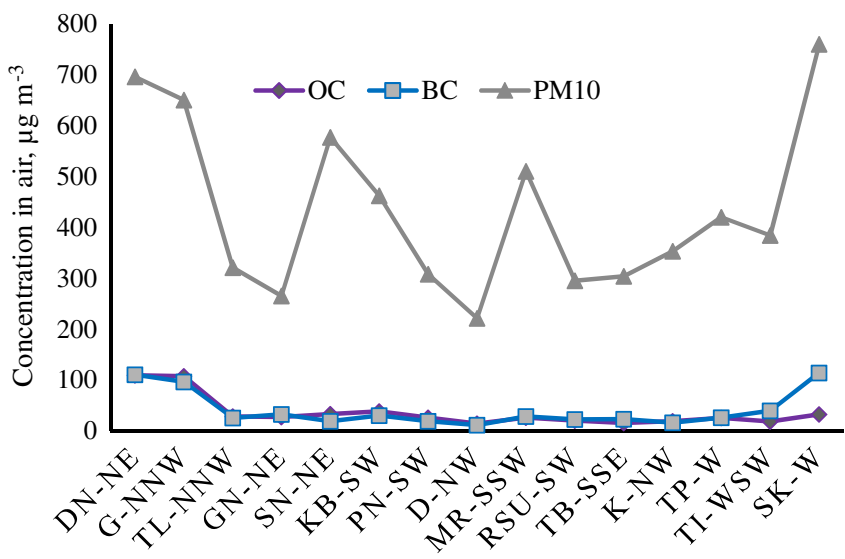

(a)

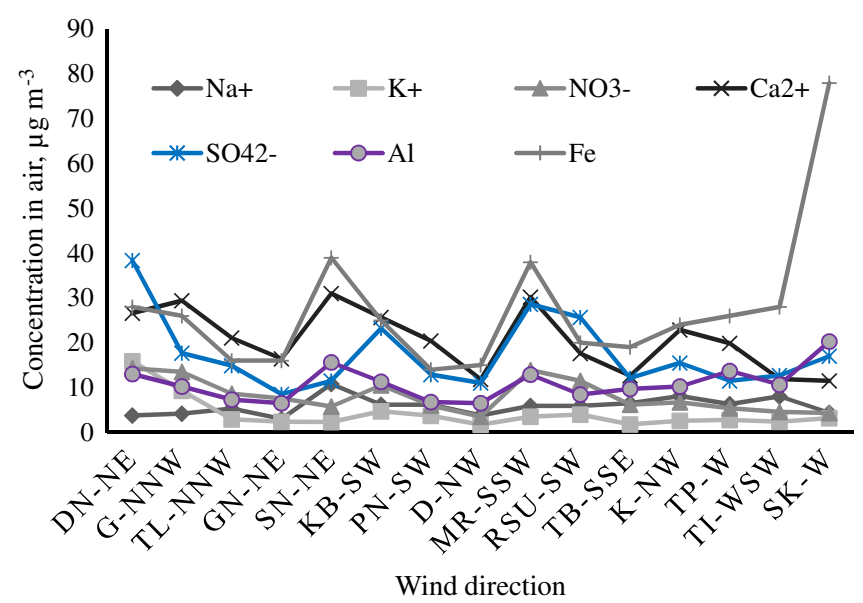

(b)

Fig. 4. Influence of wind direction in distribution of PM and associated species. $\mathrm{NE}=$ northeast; $\mathrm{NNW}=$ north-northeast; $\mathrm{NE}=$ north east; $\mathrm{SW}=$ southwest; $\mathrm{NW}=$ northwest; SSW = south-southwest; SSE = south-southeast NW = northwest; $\mathrm{W}=$ west; and WSW = west-southwest.

found when the air masses come from the northeast direction due to influence of local industries (Fig. 4). The significant concentration of $\mathrm{OC}$ and $\mathrm{Cl}^{-}$was seen when the air masses come from the northnorthwest direction due to industrial influence of the Bhilai Steel Plant. The remarkable high mass concentration of the secondary aerosol species, i.e., $\mathrm{NO}_{3}^{-}$and $\mathrm{SO}_{4}^{2-}$, was seen when the air masses flowed from the south-southwest direction due to thermal power plants running in Nagpur and Chandrapur areas. The highest concentration of $\mathrm{Ca}^{2+}$ was assumed to be due to running of several rice mills in the south-southwest direction of the city.

The widely used principle component analysis-multilinear regression analysis (PCA-MLRA) was used to apportion the emission sources contributing to the ambient particulates in Raipur (USEPA 1997; John et al. 1994). Four factors (Table 5) were identified as per criteria of cumulative percentage variance $>80 \%$ and eigenvalue of $>2$ (Stevens 1996). The Varimax rotated factor analysis showed four possible different sources for the $\mathrm{OC}, \mathrm{BC}$, metallic elements (ME), and water soluble ions (WSI). Factor 1 comprised of anthropogenic sources with influence of traffic for $\mathrm{OC}, \mathrm{BC}, \mathrm{K}^{+}, \mathrm{Mg}^{2+}, \mathrm{SO}_{4}^{2-}, \mathrm{NO}_{3}^{-}$, and $\mathrm{Cl}^{-}$with a variance of $37 \%$. A substantial amount of coal (>10 $\left.\mathrm{Mtyear}^{-1}\right)$ was burned in Raipur City and surrounding areas by various industries. This means that the pollutants originated by the fuel combustion as well
Table 5. Factor loadings (varimax normalized)

\begin{tabular}{lrrrr}
\hline Species & Factor $\mathrm{I}$ & Factor 2 & Factor 3 & Factor 4 \\
\hline $\mathrm{OC}$ & 0.95 & 0.06 & -0.02 & 0.06 \\
$\mathrm{BC}$ & 0.70 & 0.41 & -0.41 & -0.17 \\
$\mathrm{Na}^{+}$ & -0.20 & 0.13 & 0.86 & 0.12 \\
$\mathrm{~K}^{+}$ & 0.89 & 0.04 & 0.02 & 0.28 \\
$\mathrm{Mg}^{2+}$ & 0.62 & 0.30 & 0.30 & 0.35 \\
$\mathrm{Ca}^{2+}$ & 0.43 & 0.02 & 0.57 & 0.44 \\
$\mathrm{NH}_{4}^{+}$ & -0.03 & 0.03 & 0.04 & 0.87 \\
$\mathrm{SO}_{4}^{2-}$ & 0.54 & 0.19 & -0.03 & 0.74 \\
$\mathrm{NO}_{3}^{-}$ & 0.61 & -0.10 & 0.24 & 0.67 \\
$\mathrm{Cl}^{-}$ & 0.90 & 0.07 & 0.21 & 0.08 \\
$\mathrm{Al}$ & 0.08 & 0.94 & 0.13 & -0.03 \\
$\mathrm{P}$ & 0.02 & 0.11 & 0.47 & -0.51 \\
$\mathrm{TI}$ & 0.08 & 0.93 & 0.15 & -0.10 \\
$\mathrm{Cr}$ & -0.03 & 0.62 & -0.42 & 0.31 \\
$\mathrm{Mn}$ & 0.27 & 0.69 & -0.43 & 0.32 \\
$\mathrm{Fe}$ & 0.06 & 0.93 & 0.09 & -0.06 \\
$\mathrm{Cu}$ & -0.11 & 0.09 & -0.81 & 0.06 \\
$\mathrm{Zn}$ & 0.43 & 0.68 & -0.12 & 0.07 \\
Variance & 5.42 & 4.33 & 2.77 & 2.69 \\
Total & 0.28 & 0.23 & 0.15 & 0.14 \\
\hline & & & &
\end{tabular}

as blown dust. Factor 2 included mineral sources for $\mathrm{Al}, \mathrm{Ti}, \mathrm{Cr}$, $\mathrm{Mn}, \mathrm{Fe}$, and $\mathrm{Zn}$ with a variance of $19 \%$. This pattern of metals indicated the originated from the roasting of the raw materials and blown dust. Factor 3 traced a consistent source for $\mathrm{Na}^{+}$and $\mathrm{Ca}^{2+}$ with a variance of $14 \%$. Mainly three sources, i.e., roasting of pyrite and dolomite, fossil fuel combustion, and blown dust, contributed to a continuous presence of $\mathrm{Na}^{+}$and $\mathrm{Ca}^{2+}$ in the coarse particulates. Factor 4 predicted secondary sources for specie $\mathrm{NH}_{4}^{+}$, $\mathrm{SO}_{4}^{2-}$, and $\mathrm{NO}_{3}^{+}$with a variation of $11 \%$.

\section{Conclusion}

The severe particulate air pollution (more than eightfold higher than the prescribed value), especially in the period December to January in Raipur City, India, was observed to be due to adverse climatic weather. The particulates were composed of high fractions of $\mathrm{BC}(9.4 \%)$, OC (11.2\%), metals $(9.2 \%)$, and watersoluble ions (26.2\%). Anthropogenic activities and atmospheric transformations were expected to be major sources of PM and associated species in the air. Wind speed was observed as one major meteorological factor responsible for the halting of winter particulate pollution.

\section{Acknowledgments}

This work was supported through Grant No. ES/48/ICRP/008/2002 funded by the Department of Science and Technology, New Delhi. It was also partially funded by the Spanish Ministry of Education and Science, Madrid.

\section{References}

Awad, A. M., and A. W. S. Mashat. 2016. "Synoptic characteristics of spring dust days over northern Saudi Arabia." Air Qual. Atmos. Health 9 (1): 41-50. https://doi.org/10.1007/s11869-015-0320-0.

Begum, B. A., S. K. Biswas, and P. K. Hopke. 2006. "Temporal variations and spatial distribution of ambient $\mathrm{PM}_{2.2} 10$ concentrations in Dhaka, Bangladesh." Sci. Total Environ. 358 (1-3): 36-45. https://doi.org/10 .1016/j.scitotenv.2005.05.031. 
Bell, M., and T. Holloway. 2007. "Global impacts of particulate matter air pollution.” Environ. Res. Lett. 2 (4): 045026. https://doi.org/10.1088 /1748-9326/2/4/045026.

Calzolai, G., M. Chiari, I. García Orellana, F. Lucarelli, A. Migliori, S. Nava, and F. Taccetti. 2006. "The new external beam facility for environmental studies at the tandetron accelerator of LABEC." Nucl. Instrum. Methods Phys. Res. B. 249 (1-2): 928-931. https://doi.org/10 .1016/j.nimb.2006.03.193.

Costa, V., D. Bacco, S. Castellazzi, I. R. Ricciardelli, R. Vecchietti, C. Zigola, and M. C. Pietrogrande. 2016. "Characteristics of carbonaceous aerosols in Emilia-Romagna (northern Italy) based on two fall/ winter field campaigns." Atmos. Res. 167: 100-107. https://doi.org/10 .1016/j.atmosres.2015.07.020.

Ding, A. J., et al. 2016. "Enhanced haze pollution by black carbon in megacities in China." Geophys. Res. Lett. 43 (6): 2873-2879. https://doi .org/10.1002/2016GL067745.

Duan, F., K. He, Y. Ma, Y. Jia, F. Yang, Y. Lei, S. Tanaka, and T. Okuta. 2005. "Characteristics of carbonaceous aerosols in Beijing, China." Chemosphere 60 (3): 355-364. https://doi.org/10.1016/j.chemosphere .2004.12.035.

Ferrante, M., M. Fiore, C. Copat, S. Morina, C. Ledda, C. G. Mauceri, and G. O. Con. 2015. "Air pollution in high-risk sites-Risk analysis and health impact." In Current air quality issues, edited by F. Nejadkoorki. Vienna, Austria: InTech.

Fortoul, T. I., et al. 2015. "Health effects of metals in particulate matter." In Current air quality issues, edited by F. Nejadkoorki. Vienna, Austria: InTech.

Gupta, A. K., K. Karar, and A. Srivastava. 2007. "Chemical mass balance source apportionment of $\mathrm{PM}_{10}$ and TSP in residential and industrial sites of an urban region of Kolkata, India." J. Hazard. Mater. 142 (1-2): 279-287. https://doi.org/10.1016/j.jhazmat.2006.08.013.

Gupta, I., and R. Kumar. 2006. "Trends of particulate matter in four cities in India." Atmos. Res. 40 (14): 2552-2566. https://doi.org/10.1016/j .atmosenv.2005.12.021.

Gupta, P., S. P. Singh, A. Jangid, and R. Kumar. 2017. "Characterization of black carbon in the ambient air of Agra, India: Seasonal variation and meteorological influence." Adv. Atmos. Sci. 34 (9): 1082-1094. https:// doi.org/10.1007/s00376-017-6234-Z.

Guttikunda, S., S. Lodoisamba, B. Bulgansaikhan, and B. Dashdondog. 2013. "Particulate pollution in Ulaanbaatar, Mongolia." Air Qual. Atmos. Health 6 (3): 589-601. https://doi.org/10.1007/s11869-013 -0198-7.

Han, B., R. Zhang, W. Yang, Z. Bai, Z. Ma, and W. Zhan. 2015. "Heavy air pollution episodes in Beijing during January 2013: Inorganic ion chemistry and source analysis using highly time-resolved measurements in an urban site." Atmos. Chem. Phys. 15 (7): 11111-11141. https://doi.org/10.5194/acpd-15-11111-2015.

John, G., J. C. Watson, Z. L. Chow, M. F. Eric, H. L. Douglas, R. L. Douglas, and L. A. Lowell. 1994. "Chemical mass balance source apportionment of $\mathrm{PM}_{10}$ during the Southern California air quality study." Aerosol Sci. Technol. 21 (1): 1-36. https://doi.org/10.1080 /02786829408959693.

Khillare, P. S., and S. Sarkar. 2012. "Airborne inhalable metals in residential areas of Delhi, India: Distribution, source apportionment and health risks." Atmos. Pollut. Res. 3 (1): 46-54. https://doi.org/10.5094/APR .2012.004.

Kulshrestha, A., D. S. Bisht, J. Masih, D. Massey, S. Tiwari, and A. Taneja. 2009. "Chemical characterization of water-soluble aerosols in different residential environments of semi arid region of India." J. Atmos. Chem. 62 (2): 121-138. https://doi.org/10.1007/s10874-010-9143-4.

Lakhani, A., R. S. Parmar, G. S. Satsangi, and S. Prakash. 2008. "Size distribution of trace metals in ambient air of Agra." Indian J. Radio Space Phys. 37: 434-442.

Latha, K. M., and K. V. S. Badrinath. 2003. "Black carbon aerosols over tropical urban environment: A case study.” Atmos. Res. 69 (1-2): 125-133. https://doi.org/10.1016/j.atmosres.2003.09.001.
Mouli, P. C., S. V. Mohan, and S. J. Reddy. 2006. "Chemical composition of atmospheric aerosol $\left(\mathrm{PM}_{10}\right)$ at a semi-arid urban site: Influence of terrestrial sources." Environ. Monit. Assess. 117 (1-3): 291-305. https://doi.org/10.1007/s10661-006-0988-6.

Oanh, N. T. K., et al. 2006. "Particulate air pollution in six Asian cities: Spatial and temporal distributions, and associated sources." Atmos. Environ. 40 (18): 3367-3380. https://doi.org/10.1016/j.atmosenv.2006 .01 .050 .

Pan, Y., S. Tian, X. Li, Y. Sun, Y. Li, G. R. Wentworth, and Y. Wang. 2015. "Trace elements in particulate matter from metropolitan regions of northern China: Sources, concentrations and size distributions." Sci. Total Environ. 537: 9-22. https://doi.org/10.1016/j.scitotenv.2015 .07 .060 .

Sati, A. P., and M. Mohan. 2014. "Analysis of air pollution during a severe smog episode of November 2012 and the Diwali festival over Delhi, India." Int. J. Remote Sens. 35 (19): 6940-6954. https://doi.org/10.1080 /01431161.2014.960618.

Satsangi, A., T. Pachauri, V. Singla, A. Lakhani, and K. M. Kumari. 2013. "Water soluble ionic species in atmospheric aerosols: Concentrations and sources at Agra in the Indo-Gangetic Plain (IGP)." Aerosol Air Qual. Res. 13 (6): 1877-1889. https://doi.org/10.4209/aaqr.2012.08 .0227 .

Sillanpaa, M., A. Frey, R. Hillamo, A. S. Pennanen, and R. O. Salonen. 2005. "Organic, elemental and inorganic carbon in particulate matter of six urban environments in Europe." Atmos. Chem. Phys. 5 (11): 2869-2879. https://doi.org/10.5194/acp-5-2869-2005.

Singh, K., S. Tiwari, A. K. Jha, S. G. Aggarwal, D. S. Bisht, B. P. Murty, Z. H. Khan, and P. K. Gupta. 2013. "Mass-size distribution of $\mathrm{PM}_{10}$ and its characterization of ionic species in fine $\left(\mathrm{PM}_{2.5}\right)$ and coarse $\left(\mathrm{PM}_{10-2.5}\right)$ mode, New Delhi, India." Nat. Hazards 68 (2): 775-789. https://doi.org/10.1007/s11069-013-0652-8.

Stevens, J. 1996. Applied multivariate statistics for the social sciences. 3rd ed. Mahwah, NJ: Lawrence Erlbaum Associates.

Tao, Y., Z. Yin, X. Ye, Z. Ma, and J. Chen. 2014. "Size distribution of water-soluble inorganic ions in urban aerosols in Shanghai." Atmos. Pollut. Res. 5 (4): 639-647. https://doi.org/10.5094/APR.2014.073.

USEPA. 1997. "CMB8 chemical mass balance receptor model version 8 user manual." Triangle Park, NC: USEPA Research. Accessed January 15, 2012. https://www.dri.edu/images/stories/editors/eafeditor /Watsonetal1997CMB8Manual.pdf.

USEPA. 2004. "Air quality criteria for particulate matter." Accessed January 20, 2012. https://cfpub.epa.gov/ncea/risk/recordisplay.cfm?deid $=87903$.

USEPA. 2010. “Clean Air Act.” Accessed January 22, 2012. USEPA Office of Air and Radiation. http://www.epa.gov/air/caa/.

VDI (Verein Deutscher Ingenieure) German. 1996. Measurement of soot (emission) thermographic analysis of elemental carbon by thermal desorption of organic carbon. Vol. 1, 2465. Düsseldorf, Germany: VDI.

WHO (World Health Organization). 2006. "Health risks of particulate matter from long-range transboundary air pollution." World Health Organization. Accessed January 24, 2012. http://www.euro.who.int /_data/assets/pdf_file/0006/78657/E88189.pdf.

$\mathrm{Xu}, \bar{Z}$., T. Wen, X. Li, J. Wang, and Y. Wang. 2015. "Characteristics of carbonaceous aerosols in Beijing based on 2-year observation." Atmos. Pollut. Res. 6 (2): 202-208. https://doi.org/10.5094/APR.2015.024.

Yadav, S., and P. G. Satsangi. 2013. "Characterization of particulate matter and its related metal toxicity in an urban location in south west India." Environ. Monit. Assess. 185 (9): 7365-7379. https://doi.org/10.1007 /s10661-013-3106-6.

Yttri, K. E., et al. 2007. "Elemental and organic carbon in $\mathrm{PM}_{10}$ : A 1 year measurement campaign within the European Monitoring and Evaluation Programme EMEP." Atmos. Chem. Phys. 7 (22): 5711-5725. https://doi.org/10.5194/acp-7-5711-2007.

Zeb, B., K. Alam, A. Sorooshian, T. Blaschke, I. Ahmad, and I. Shahid. 2018. "On the morphology and composition of particulate matter in an urban environment.” Aerosol Air Qual. Res. 18 (6): 1431-1447. https:// doi.org/10.4209/aaqr.2017.09.0340. 